\title{
How a New Geology and Glacial Paradigm Explains Colorado South Platte-Arkansas River Drainage Divide Topographic Map Evidence, USA
}

\author{
Eric Clausen \\ Independent Investigator, Jenkintown, USA \\ Email: eric2clausen@gmail.com
}

How to cite this paper: Clausen, E. (2021) How a New Geology and Glacial Paradigm Explains Colorado South Platte-Arkansas River Drainage Divide Topographic Map Evidence, USA. Open Journal of Geology, 11, 573-595.

https://doi.org/10.4236/ojg.2021.1111029

Received: October 6, 2021

Accepted: November 7, 2021

Published: November 10, 2021

Copyright $\odot 2021$ by author(s) and Scientific Research Publishing Inc. This work is licensed under the Creative Commons Attribution International License (CC BY 4.0).

http://creativecommons.org/licenses/by/4.0/ (c) (i) Open Access

\begin{abstract}
United States Geological Survey (USGS) topographic maps (available at the USGS National Map website) are used to determine development of the asymmetric South Platte River drainage basin (south of Denver) by noting low points (referred to as divide crossings) where south-oriented floodwater channels once crossed the South Platte-Arkansas River drainage divide. Twelve groups of observed divide crossings are described most of which show evidence for flood-formed diverging and converging channels including where divide crossings are cut across Thirtynine Mile volcanic field ejectamenta. A new Cenozoic geologic and glacial history paradigm requires southeast- and south-oriented floods to have flowed across what is now the east-west continental divide to reach the southeast-oriented Arkansas River valley and to have eroded the divide crossings before north-oriented South Platte River valley headward erosion captured the flow. Such floods are not consistent with accepted Cenozoic geologic and glacial history interpretations, but are consistent with new paradigm interpretations (developed to explain Missouri River drainage basin topographic map drainage system evidence) in which a thick continental ice sheet (located where large continental ice sheets are usually reported to have been) deeply eroded the underlying bedrock and caused crustal uplift to create a deep "hole" with a deep "hole" rim segment roughly following today's Wyoming and northern Colorado east-west continental divide and then continuing eastward along what is now the Missouri-Arkansas River drainage divide. The new paradigm results in a Cenozoic geologic and glacial history in which immense south-oriented continental ice sheet meltwater floods first flowed in a south direction across the rising deep "hole" rim and were then forced by rim uplift to flow along the rim and
\end{abstract}


subsequently in north directions into the developing deep "hole".

\section{Keywords}

Divide Crossings, Drainage Divides, Geomorphology, Mosquito Range, South Park, Tarryall Creek

\section{Introduction}

\subsection{Statement of the Research Problem}

To a geomorphologist the South Platte River drainage system south of Denver (see Figure 1 and Figure 2) contains intriguing features, but perhaps the most striking is the asymmetric drainage basin with long southeast-oriented headwaters and tributaries flowing to a north-northeast oriented South Platte River valley. Just as interesting are headwaters and tributaries flowing from North America's east-west continental divide in southeast directions yet instead of continuing in straight lines to reach the nearby southeast- and east-oriented Arkansas River (which flows to the south-oriented Mississippi River) South Platte River water makes a sharp northward turn to add thousands of kilometers to its travel route by flowing first through deep mountain valleys to reach the plains and then the Platte River, the Missouri River, and eventually the south-oriented Mississippi River. Surprisingly, little or no published geomorphology literature mentions how drainage system and erosional landforms seen on United States Geological Survey (USGS) topographic maps (available at the USGS National Map website) can be used to reconstruct how these rather odd South Platte River drainage system features developed.

The geologic research community's failure to say much about South Platte River drainage system history is intriguing because published reports say much more about the regional geologic structures, stratigraphy, volcanic activity, economic resources, and paleontology than they say about the regional drainage history. For example, two recent Colorado Geological Survey reports [1] [2] describe Park County geology but hardly mention the regional drainage history even though significant regional South Platte River drainage history events must have occurred. This failure to determine regional drainage histories is not unique to the South Platte River headwaters region and shows up in geologic literature pertaining to most other drainage systems. While geologists rarely say so, they are reluctant to determine regional drainage histories because the drainage histories determined from detailed topographic maps (on which drainage history evidence is most easily observed) frequently do not agree with commonly accepted Cenozoic geology and glacial history paradigm (accepted paradigm) interpretations.

According to Thomas Kuhn [3] the geology research community has consciously and/or unconsciously determined (usually without saying so) that most 


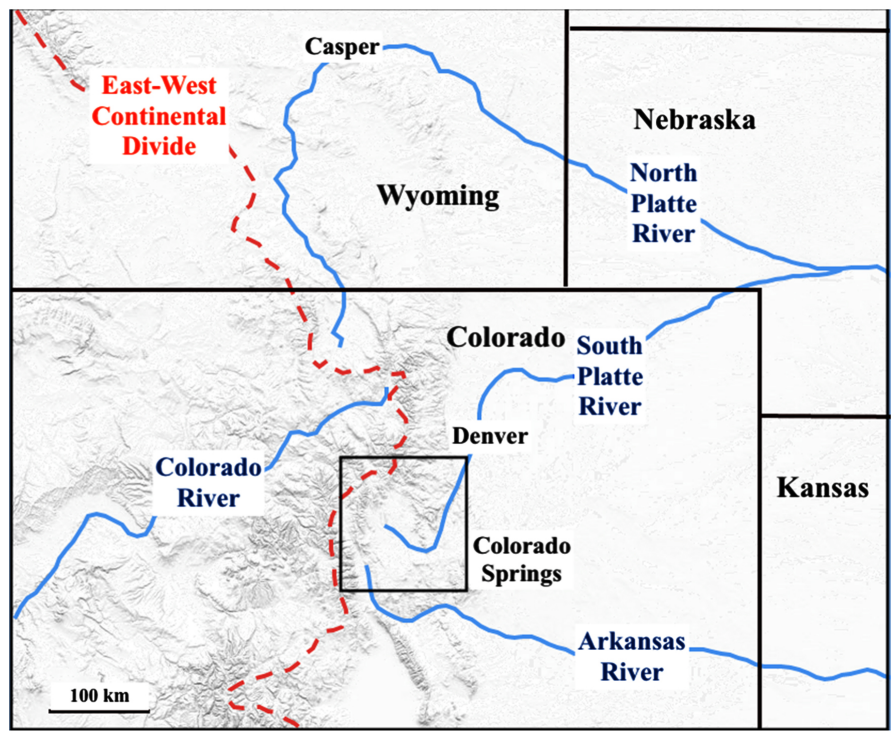

Figure 1. Modified map from United States Geological Survey (USGS) National Map website showing study region (black rectangle) in relation to major regional rivers, the North American east-west continental divide, and state boundaries.

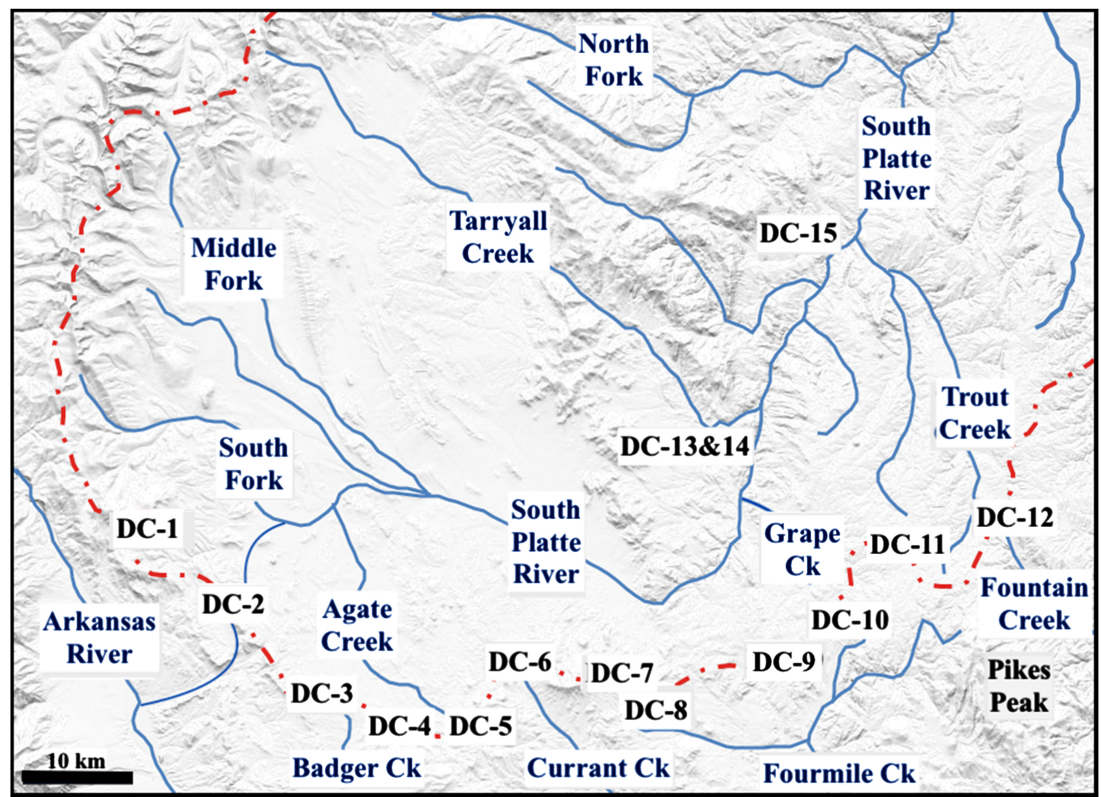

Figure 2. Modified map from USGS National Map website showing the asymmetric South Platte River headwaters drainage basin. Red dashed line shows east-west continental divide and South Platte-Arkansas River drainage divide locations.

topographic map drainage system and erosional landform evidence is anomalous evidence not worth trying to explain. Other types of geologic evidence are then used to flesh out Cenozoic geologic and glacial histories while (consciously or unconsciously) assuming that at some future time geologists will use those fleshed out Cenozoic geologic and glacial histories as guides in figuring out how to explain the anomalous topographic map drainage system and erosional landform evidence. This commonly used, but rarely expressed research strategy has 
been applied for many decades and is unfortunate because USGS detailed topographic maps provide much of the information needed to easily reconstruct former drainage routes and having a knowledge of prior drainage routes is critical if geologists want to correctly understand a region's Cenozoic geologic and glacial history.

The author of this paper [4] recently used Missouri River drainage basin topographic map evidence to construct a paradigm (new paradigm) able to explain topographic map drainage system and erosional landform features. This new paradigm explains most Missouri River drainage basin topographic map drainage system and erosional landform evidence by requiring a thick North American continental ice sheet (located where large continental ice sheets are usually thought to have been) that deeply eroded the underlying bedrock (accepted paradigm ice sheets did not deeply erode the underlying bedrock) and that weighed enough to raise surrounding regions to create a deep "hole" in which the thick ice sheet was located and in which a much thinner ice sheet later formed (accepted paradigm ice sheets did not cause surrounding region uplift or create a deep "hole"). The new paradigm's deep "hole" southwest rim rose as massive south-oriented meltwater floods flowed across it and was located along what is today the Montana, Wyoming, and northern Colorado east-west continental divide and then continued eastward roughly following today's Missouri River-Arkansas River drainage divide. Present day drainage patterns evolved as valleys eroded headward to capture the massive meltwater floods and as mountain and regional uplift forced floodwaters to flow along the deep "hole" rim and subsequently into deep "hole" space being opened up as the large ice sheet melted. The completely different and incompatible accepted and new paradigms lead to incompatible Cenozoic geologic and glacial histories. This paper describes how the new paradigm explains some of the yet to be explained South Platte River headwaters region topographic map drainage system and erosional landform evidence.

\subsection{Geographic Setting}

The South Platte River headwaters drainage basin (south of Denver) is located in central Colorado and is bounded on the northwest by mountains forming the North American east-west continental divide (with the southwest-oriented Colorado River headwaters drainage basin on the other side and the north-oriented North Platte River headwaters drainage basin to the north of the Colorado River headwaters drainage basin), on the west and southwest by the Mosquito Range (which forms a segment of the South Platte River-Arkansas River drainage divide), on the south and southeast by the Thirtynine Mile volcanic field including the largely eroded Guffey volcano and other hills (which are also located along the South Platte River-Arkansas River drainage divide), and on the east and north by the Rampart Range (including Pikes Peak) and the Front Range. Much of the South Platte River headwaters drainage basin is located in South Park, which when compared with surrounding mountains is a relatively flat inter- 
montane basin. In the southern half of South Park Stark et al. [5] describe a southward-sloping erosion surface beveling Miocene and Pliocene rocks which they say formed when South Park drained in a south direction to the Arkansas River.

Fenneman ([6]: p. 103-104) describes South Park as a peneplain surface about 80 kilometers in diameter at an altitude ranging from less 2743 to more than 3048 meters which "extends in some areas eastward with increasing dissection from the Park to the foothills. On the south there is no sharp limit short of the Arkansas River". Thornbury ([7]: p. 343) comments "Actually much of the Park does have low relief, but there is diversity of topography in the form of pediments, stream terraces, lateral and terminal moraines, and outwash plains". The South Platte River is formed in South Park at the confluence of its generally southeast-oriented South Fork and Middle Fork (both of which begin in the surrounding mountains) and then flows in a southeast direction before turning in a northeast direction to leave South Park proper and flow through Elevenmile Canyon before turning in a north direction to cross the Front Range, although southeast-oriented Tarryall Creek, which also begins along the east-west continental divide flows through northern South Park before reaching the north-oriented South Platte River. Further north the North Fork (South Platte River) begins at the continental divide and flows in southeast, east, and northeast directions through mountainous regions before joining the north-oriented South Platte River.

\subsection{Previous Work-Accepted Paradigm Interpretations}

River canyons crossing Rocky Mountain ranges and evidence for high-level Rocky Mountain erosion surfaces intrigued early geomorphologists who lacked the good quality topographic maps available today. High-elevation peneplains (or erosion and deposition surfaces) were proposed to have extended across the Colorado Front Range area on which today's drainage systems formed (although details of drainage system formation were rarely given). Regional uplift enabled what were proposed to be superimposed drainage systems to cut into the underlying mountains and to remove basin fills that had partially buried mountain ranges and to excavate or partially excavate intermontane basins. For example, Atwood ([8]: p. 315) comments "Late in Tertiary time, after the mountain ranges had been subdued, after thousands of feet [meters] of mid-Tertiary sediments had accumulated, after the great volcanic flows of Colorado... had poured forth, after the vast quantities of ejectamenta had settled and accumulated as breccias, tuffs, and ash beds, and just before the opening of the Pleistocene period" the entire Rocky Mountain region was uplifted and streams that had been flowing over buried mountain ranges lowered their channels so as to produce the gorges and water gaps seen today. This superposition hypothesis has been rarely challenged, although Pelletier ([9]: p. 5) cites several researchers who suggest middle "Cenozoic peak elevations were as high or higher than today" and proposes climate change as an alternate explanation for the southern Rocky Mountain re- 
gion late Cenozoic erosion.

Determining details of the South Platte River headwaters drainage development does not appear to have been a previous research priority, although some investigators saw evidence for a south-oriented drainage system flowing to the Arkansas River prior to the present-day north-oriented South Platte River canyon. Stark et al. ([5]: p. 141) for example, based on previously mentioned southoriented South Park regional slopes suggested southeast-oriented South Platte River headwaters once flowed to the Arkansas River and were shifted (by volcanic activity and possible regional uplift) to flow in an "east" direction [they probably meant in a "north" direction]. Thornbury, ([7]: p. 344) attributes the South Park drainage diversion to regional uplift and tilting. Epis and Chapin ([10]: Figure 9, p. 58) identify on plastic relief maps (U.S. Army Map Service $2^{\circ}$ quadrangles) south-oriented paleovalleys leading from the South Platte River headwaters area to the Arkansas River and discuss regional deformation, but like Stark et al. and Thornbury do not describe the capture events required to shift south-oriented drainage from the nearby Arkansas River northward to the more distant Platte and Missouri Rivers.

The Guffey volcano and associated Thirtynine Mile Mountain volcanic materials are sometimes described as having formed on a late Eocene erosion surface (or peneplain) and are located along what is now the South Platte River-Arkansas River drainage divide. Epis and Chapin ([10]: p. 57) indicate the Guffey volcano flanks "are well preserved in an elliptical ring of mountains composed of outward-dipping andesitic flows and breccias. The steepest dips are to the north $\left(10^{\circ}\right.$ to $\left.15^{\circ}\right)$ on Thirtynine Mountain and to the west $\left(8^{\circ}\right)$ on Black Mountain. To the east... the flows have dips of only $2^{\circ}$ to $6^{\circ}$. The gentlest dips are to the southeast where andesitic lavas flowed at least $11 \mathrm{~km}$ down a paleovalley." The cover of McGookey's book [11] shows a large stratovolcano rising above this ring although not all previous investigators agree with his interpretation. Detailed 1:62,500 scale geologic maps by Wobus and Epis [12] and Epis et al. [13] document extrusive igneous rocks, mudflows, and related materials covering the area where the Guffey stratovolcano supposedly stood. Today deep north-to-south oriented through valleys crossing the South Platte River-Arkansas River drainage divide are eroded on either side of the east-to-west oriented Thirtynine Mile Mountain. If a high stratovolcano formed in Oligocene time as sometimes proposed subsequent volcanic activity and/or water erosion has almost completely removed that large mountain.

McGookey ([11]: p. 143) attributes diversion of South Park drainage to the north-oriented South Platte River to Guffey volcano related mudflows which "dammed the pre-Oligocene south-flowing drainage and caused a large lake to develop over South Park and in the Florissant Valley. The outlet from the South Park Lake became the South Platte River, which is superimposed across the Front Range". Earlier he commented (p. 33) "Just why the river cut a straight northeast trending canyon has not been explained. There is no obvious line of weakness". Meyer et al. ([14]: p. 155) describe how lahars of the Thirtynine Mile 
andesite (from the Guffey volcano to the west) blocked paleo-drainage routes to create Lake Florissant (in which sediments including volcanic ash containing the Florissant fossil beds were deposited). The "lahars originated from the slopes of the Guffey volcanic center [and] flowed into the surrounding paleovalleys, some of these lahars flowed down the ancestral paleodrainage of Four Mile Creek to its confluence with the Florissant paleovalley, where they formed a natural dam... This impoundment of the drainage created the late Eocene 'Lake Florissant' to the north and it was in this basin that the Florissant Formation accumulated". Whether the lahars blocked all south-oriented drainage routes to form the lake(s) McGookey describes has been debated and Benson ([15]: p. 15) states "It is reasonable to conclude, therefore, that the original areal extent of the lake paleobasin is unknown; and that, as a result, much information about the original topography and the nature of the catchment area is unknown".

Efforts to explain South Platte River headwaters drainage system history in a manner consistent with accepted paradigm Cenozoic geologic and glacial histories have produced general hypotheses in which volcanic and/or tectonic activity blocked an earlier south-oriented drainage system to create the north-oriented South Platte River drainage system, but most details are left to the reader's imagination. Previous researchers do not report using topographic map evidence to conduct simple tests such as studying low points (or divide crossings) along the South Platte River-Arkansas River drainage divide to determine how blockage of earlier south-oriented drainage routes explains the map evidence. As this paper describes low points (or divide crossings) along the South Platte River-Arkansas River drainage divide indicate multiple streams of south-oriented water (some flowing in complexes of diverging and converging channels) eroded the volcanic and mudflow deposits claimed by some previous researchers to have blocked the south-oriented drainage routes. While evidence for at least some blockage and lake formation is good the topographic maps show evidence for large south-oriented flood flows that occurred after the blockages and makes it difficult to explain how the north-oriented South Platte River canyon developed. The topographic map evidence indicates the rather vague accepted paradigm hypotheses leave out many important details.

\subsection{Previous Work-New Paradigm Interpretations}

The new paradigm explains Missouri River drainage basin topographic map evidence by describing how almost all valleys were eroded headward across and along massive continental ice sheet meltwater floods. The floods flowed across rising mountain ranges and regions as the thick ice sheet weight caused crustal uplift which formed a deep "hole" in which the ice sheet was located (where continental ice sheets are usually reported to have been). Describing how the new paradigm explains 37 high elevation mountain passes crossing the Colorado east-west continental divide Clausen ([16]: p. 61) says "passes leading from the North Platte River drainage basin to the southeast-oriented Muddy Creek valley and from the Blue River drainage basin to the South Platte River headwaters 
suggest south- and southeast-oriented diverging and converging channels from what is now the north-oriented North Platte River drainage basin initially moved water across what must have been rising mountain ridges into the southeast-oriented South Platte River headwaters area. Colorado River valley headward erosion, probably aided by regional and mountain uplift, captured the south-southeast oriented flow, which reversed flow on the beheaded channels to create what are today the north-northwest oriented Blue River drainage system and the Colorado River-South Platte River drainage divide".

Another new paradigm demonstration paper [17] describes how topographic map evidence shows how mountain uplift blocked south-oriented floodwaters that were moving from the now north-oriented North Platte River headwaters area into the Colorado River valley and forced the floodwaters to make a U-turn so as to flow in a north direction into the Laramie Basin and then across the rising Laramie Range as described in an earlier new paradigm demonstration paper [18] to reach what was at that time an actively eroding southeast-oriented North Platte River valley. Still another new paradigm demonstration paper [19] describes how headward erosion of that southeast-oriented North Platte River valley (along the northern Laramie Mountains northeast margin) beheaded and reversed south-oriented floodwaters flowing into the Laramie Basin and next beheaded and reversed flood flow moving south from the Casper, Wyoming area into north central Colorado to create the north-, east-, and southeast-oriented North Platte River route seen in Figure 1. Topographic map evidence is also used in two other new paradigm demonstration papers [20] [21] to show how a northeast-oriented South Platte River valley segment eroded headward across massive south-oriented floods from the western Nebraska North Platte-South Platte River confluence area into northeast Colorado. In summary, published new paradigm demonstration papers have interpreted detailed topographic map drainage system and erosional landform evidence to reconstruct how much of the previously unexplained North Platte and South Platte River drainage systems developed.

Not yet documented in published new paradigm demonstration papers is a test of the new paradigm prediction that deep "hole" rim area uplift enabled east- and northeast-oriented South Platte River valley headward erosion (north of Denver) to behead and reverse south-oriented floodwaters which had been moving across a rising Front Range (south of Denver) to join southeast-oriented floodwaters flowing across what is now the Colorado River (headwaters area)South Platte River (headwaters area) drainage divide (now the east-west continental divide) and then to continue flowing in a south direction to what must have been an actively eroding Arkansas River valley. Prior to Arkansas River valley headward erosion the new paradigm predicts those floodwaters flowed to what are now the Rio Grande River and Pecos River drainage basins and in northeast New Mexico that headward erosion of the Canadian River valley captured some of the south-oriented flood flow (predictions which can be tested by observing detailed topographic map drainage system and erosional landform 
evidence). This new paradigm demonstration paper begins the testing process by documenting how evidence shown on detailed topographic maps documents how headward erosion of what must have been a deeper reversed flow valley in what is now the north-oriented South Platte River valley captured massive south-oriented floods which had been flowing to the Arkansas River valley.

\section{Research Method}

This study began by using detailed topographic maps available at the USGS National Map website to determine whether volcanic activity had blocked south-oriented drainage and formed lakes, which then drained in a north direction as some previous investigators have suggested. Map study consisted of following (on detailed topographic maps) today's South Platte River-Arkansas River drainage divide from the Weston Pass area in the Mosquito Range eastward to Devils Head area in the Rampart Range and by noting low points (referred to here as divide crossings) where one or more streams once flowed across what is now the drainage divide. Elevations were obtained by using the spot elevation tool available at the USGS National Map website. Table 1 lists twelve of the more obvious divide crossings or groups of divide crossings observed along with the present-day opposing drainage routes, lowest drainage divide floor elevations, and elevations where the north-oriented drainage now reaches the South Platte River. At most listed divide crossing locations multiple divide crossings

Table 1. Divide crossing groups along the South Platte River-Arkansas River drainage divide showing approximate lowest floor elevation and elevations where north-oriented drainage reaches the South Platte or South Fork South Platte River. See text for details.

\begin{tabular}{cccccc}
\hline No. & $\begin{array}{c}\text { Divide } \\
\text { crossing name }\end{array}$ & $\begin{array}{c}\text { South Platte River } \\
\text { drainage route }\end{array}$ & $\begin{array}{c}\text { Arkansas River } \\
\text { drainage route }\end{array}$ & $\begin{array}{c}\text { Divide crossing } \\
\text { floor elevation } \\
(\mathrm{m})\end{array}$ & $\begin{array}{c}\text { Elevation at } \\
\text { South Platte } \\
\text { River (m) }\end{array}$ \\
\hline DC-1 & Weston Pass & South Fork South Platte River & Big Union Ck & 3634 & n/a \\
DC-2 & Trout Creek Pass & South Fork Salt Creek & Trout Ck & 2895 & 2726 \\
DC-3 & Unnamed on map & Agate Ck tributary & Badger Ck & 2865 & 2719 \\
DC-4 & Unnamed on map & Little Agate Creek & Wagon Tongue Ck & 2912 & 2719 \\
DC-5 & Unnamed on map & To Badger Ck & Thirtyone Mile Ck & 3075 & 2719 \\
DC-6 & Currant Ck Pass & Threemile Creek tributary & Currant Ck & 2892 & 2625 \\
DC-7 & Unnamed on map & Ranger Station Gulch & West Fourmile Ck & 2912 & 2609 \\
DC-8 & Unnamed on map & Fish Creek & Brooker Gulch to Cobb Ck & 2853 & 2422 \\
DC-9 & Unnamed on map & Fish Creek & Slater Ck & 2685 & 2422 \\
DC-10 & Unnamed on map & Grape Creek tributary & Hay Ck tributary & 2615 & 2416 \\
DC-11 & Unnamed on map & Rule Creek to Trout Creek & Fourmile Ck & Fountain Ck & 2865 \\
DC-12 & Woodland Park area & Trout Creek & & &
\end{tabular}


were observed and interpreted to be evidence that diverging and converging streams of water had once flowed across what is now the South Platte River-Arkansas River drainage divide. Large floods which overwhelmed existing drainage systems and spilled across drainage divides were interpreted to have formed the diverging and converging channels. Next, barbed tributaries joining northeast- and north-oriented South Platte River segments were studied to determine how headward erosion of north-oriented South Platte River valley segments captured south- and southeast-oriented flood flow as described in the results section below.

\section{Results}

Weston Pass in the Mosquito Range (DC-1 in Table 1 and in Figure 2) is one of several passes linking South Fork South Platte River tributary valleys with Arkansas River tributary valleys. Weston Pass links southeast, east-, and south-oriented South Fork South Platte River headwaters with north-northeast oriented Big Union Creek headwaters, although Big Union Creek turns in west-southwest and south-southwest directions before joining the south-southeast oriented Arkansas River. Weston Pass is eroded along the north-northwest-to south-southeast oriented Weston Fault [22] and was eroded by south-southeast oriented water which was beheaded and reversed by headward erosion of the deeper west-southwest oriented Big Union Creek valley segment from what must have been an actively eroding south-southeast oriented Arkansas River valley. To the north of Weston Pass the Mosquito Range forms a high and narrow glacially carved mountain ridge (generally exceeding 4000 meters in elevation) located between southsoutheast oriented Arkansas River and South Platte River headwaters. While glacial erosion has altered the northern Mosquito Range the high north-to-south oriented ridge probably formed as an erosional remnant between the headward eroding south-southeast oriented Arkansas River and south-southeast oriented Middle Fork South Platte River valleys.

To the south of Weston Pass the Mosquito Range is a zigzagging ridge, which is almost everywhere lower than 4000 meters and which probably also formed as an erosional remnant between the deep south-southeast oriented Arkansas River valley to the west and the southeast-, east-, and south-oriented South Fork South Platte River valley to the east. Supporting an interpretation that diverging and converging flood flow channels eroded the deep valleys on either side of the ridge is a high-altitude divide crossing between north- and east-oriented Rich Creek and north- and northeast-oriented Rough and Tumbling Creek, both flowing to the South Fork South Platte River which when viewed with similar divide crossings to the north suggests a south-oriented stream of water once flowed from Weston Pass along what are now the north-oriented Rich Creek and Rough and Tumbling Creek segment alignments and then into the southoriented Fourmile Creek valley, which joins the south-southeast oriented Arkansas River. East and West Buffalo Peaks with elevations slightly higher than 
4000 meters represent the only Mosquito Range mapped Cenozoic igneous rock area [10].

Trout Creek Pass (DC-2) has a northeast-to-southwest orientation and is used by US Highways 24 and 285 and abandoned railroad lines and is eroded across the north-northwest to south-southeast oriented Kaufman Ridge northern end. To the north of the pass South Fork Salt Creek and Salt Creek flow for about 10 kilometers in a north-northeast direction to reach Antero Reservoir (surface elevation $2725 \mathrm{~m}$ ) which is located in the South Fork South Platte River valley. A short distance upstream from the reservoir the South Fork South Platte River flows for approximately $8 \mathrm{~km}$ in a south direction and is headed almost directly toward Trout Creek Pass. Trout Creek now flows in a south-southeast oriented valley to the west of Trout Creek Pass and south of the pass has eroded a 240-meter deep or deeper water gap across Limestone Ridge and then turns in a southwest direction to join the south-oriented Arkansas River near Johnson Village. High-elevation divide crossings to the north of the south-southeast oriented Trout Creek headwaters support the previously mentioned interpretation that multiple streams of south-southeast oriented water must have carved the high Mosquito Range ridge.

Trout Creek Pass, which Stark et al. [5] show may follow a fault line appears to have been eroded in sedimentary strata by a large and prolonged stream of water that must have flowed from what is now the south-oriented South Fork South Platte River alignment (upstream from Antero Reservoir) across Trout Creek Pass to reach south-southeast oriented water on the Trout Creek headwaters alignment and which was subsequently captured by headward erosion of the southwest-oriented Trout Creek valley. South-oriented flow across Trout Pass was subsequently beheaded and reversed to create north-oriented Salt Creek drainage by South Fork South Platte River valley headward erosion (which also involved beheading and reversal of a different south-oriented flood flow channel to create a north-oriented South Fork South Platte River segment between Antero Reservoir and Hartsel). The southwest-oriented Mushroom Gulch water gap across Kaufman Ridge suggests the south-oriented stream diverged to the east of Trout Creek Pass with some water flowing in a south-southeast direction along the Kaufman Ridge east flank before turning in southwest direction to erode the Mushroom Gulch water gap and then to join Trout Creek while a diverging stream of water flowed across Trout Creek Pass to join the south-southeast oriented Trout Creek alignment west of Kaufman Ridge and to converge with the Mushroom Gulch water gap stream of water just south of the Trout Creek Limestone Ridge water gap.

Unnamed divide crossing DC-3 (between a north-oriented Agate Creek tributary and south-oriented Badger Creek) has a north-to-south orientation and on detailed topographic maps shows at least two separate divide crossings with the western one having a floor elevation of about 2865 meters and the eastern one a floor elevation of about 2869 meters. The erosional remnant between the two divide crossings rises to 2893 meters (a case can also be made for additional 
shallower divide crossings). Agate Mountain to the east rises to 3048 meters and ridges to the west rise even higher. To the north Agate Creek tributaries and Agate Creek flow in north-oriented valleys to join the north-oriented South Fork South Platte River segment between Antero Reservoir and Hartsel. To the south Badger Creek flows in a south direction to join a southeast-oriented Arkansas River segment. Large and probably prolonged volumes of water eroded these divide crossings and must have flowed in diverging and converging channels across the present-day South Platte River-Arkansas River drainage divide before continuing to the Arkansas River valley. Headward erosion of the southeastoriented South Fork South Platte River valley beheaded and reversed the southoriented flow to create the north-oriented Agate Creek drainage and the South Platte-Arkansas River drainage divide.

To the east of Agate Mountain is DC-4 with a northeast-to-southwest orientation and floor elevation of 2912 meters linking north- and northwest-oriented Little Agate Creek (flowing to north-oriented Agate Creek) with northwest- and southwest-oriented Wagon Tongue Creek (flowing to south-oriented Badger Creek). Several other nearby, but somewhat higher elevation divide crossings link northwest-oriented Wagon Tongue Creek headwaters with west- and southwest-oriented Long Gulch (draining to south-oriented Badger Creek) and northwest-oriented Little Agate Creek headwaters with Long Gulch and westsouthwest oriented Rye Slough (also draining to Badger Creek). These and other area divide crossings are difficult to explain unless large volumes of southoriented water flowing in diverging and converging channels once moved across the region with the deeper channels capturing flow from the shallower channels and with divide crossing DC-4 being the final channel.

DC-5 links northwest-oriented Agate Creek headwaters with southeast-oriented Thirtyone Mile Creek headwaters which turn in an east direction to flow to south-southeast oriented Currant Creek and also with east-northeast oriented Dicks Creek also flowing to south-southeast oriented Currant Creek (which joins the Arkansas River upstream from southeast-oriented Royal Gorge canyon). Interestingly to the north of the Gorge Hills (through which the 380-meter deep Royal Gorge canyon is cut) a 300-meter-deep divide crossing to the northeast of Cactus Mountain and a 100-meter deep or deeper divide crossing at the east end of Eightmile Park link the south-southeast oriented Currant Creek valley with the south-oriented Sand Creek valley (draining to the Arkansas River downstream from Royal Gorge). DC-5, other Currant Creek drainage basin divide crossings, and divide crossings in the Royal Gorge area suggest large and prolonged volumes of water must have flowed in diverging and converging channels in a southeast and south-southeast direction through what is now the Currant Creek drainage basin to reach the Arkansas River in the Royal Gorge area with headward erosion of the north-oriented South Platte River valley capturing that massive south-oriented flood flow.

DC-6 is actually four different divide crossings (seen in Figure 3) located between low hills of volcanic materials where the McGookey book cover [11] 


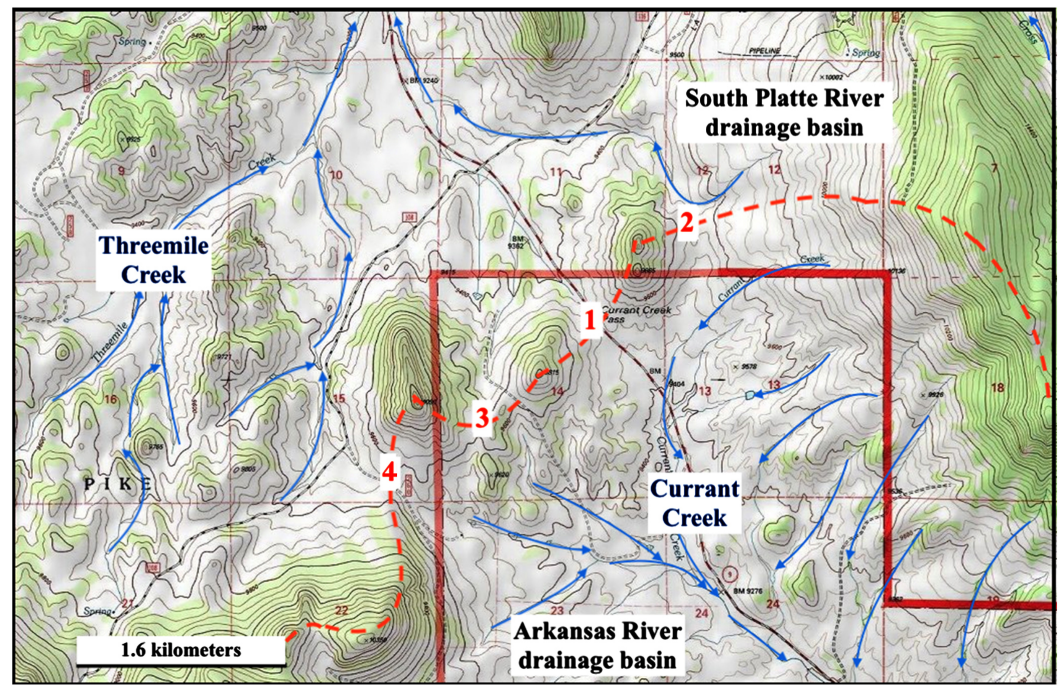

Figure 3. Modified topographic map from USGS National Map website showing Currant Creek Pass (DC-6 in table and 1 in figure) and nearby divide crossings (2, 3, and 4 in figure) and South Platte-Arkansas River drainage divide (red dashed line). Contour interval is 40 feet (12 meters).

shows the Guffey stratovolcano western flank once stood and which link north-oriented Threemile Creek tributary valleys (draining to the southeastoriented South Platte River) with south-southeast oriented Currant Creek headwaters and tributary valleys. The deepest divide crossing is north-northwestto-south-southeast oriented Currant Pass (number 1 in Figure 3) with an elevation of about 2892 meters (similar to elevations at DC-2, DC-3, and DC-4) with other divide crossing elevations in Figure 3 (numbers 2, 3, and 4 in figure) only being slightly higher. These four divide crossings are evidence large volumes of south-oriented water once flowed in diverging and converging channels through the Thirtynine Mile volcanic area and then in a south-southeast direction through the present-day Currant Creek drainage basin to reach the Arkansas River upstream from Royal Gorge. The landscape features suggest destructive volcanic activity and/or water erosion has removed almost all evidence of the hypothesized high Guffey stratovolcano (if a high stratovolcano existed as sometimes proposed). Headward erosion of the southeast oriented South Platte River valley segment beheaded and reversed the south-oriented flood flow to create the north-oriented Threemile Creek drainage basin and the South Platte River-Arkansas River drainage divide.

DC-7 is located in a 300-meter-deep valley between Thirtynine Mile Mountain (west) and Saddle Mountain (east) and has a floor elevation of 2912 meters (similar to DC-2, DC-3, DC-4, and DC-6) and links north-oriented Ranger Station Gulch (joining the South Platte River at the point where the South Platte River turns from flowing in a southeast direction to flow in a northeast direction through Elevenmile Canyon). To the south of DC-7 is east-southeast and east oriented West Fourmile Creek flowing to south-oriented Fourmile Creek, which joins the Arkansas River downstream from Royal Gorge. However, multiple 
lower-elevation divide crossings across the West Fourmile Creek-Currant Creek drainage divide suggest prior to headward erosion of the West Fourmile Creek valley large volumes of south-oriented water had flowed into what is now the Currant Creek drainage basin. A reversal of flow in what is now the northeast-oriented South Platte River valley (through Elevenmile Canyon) captured the south-oriented flow and diverted the water in a northeast direction.

DC-8 with an elevation of 2853 meters is between northeast-oriented Fish Creek headwaters (flowing to northwest-oriented Twin Creek and the northoriented South Platte River) and southeast-oriented Brooker Gulch (draining to southeast-oriented Cobb Creek and then to West Fourmile Creek and Fourmile Creek) although just as significant is an unlisted and higher divide crossing at an elevation of 2924 meters between the northeast-oriented Fish Creek headwaters and a north-northwest oriented tributary to north-oriented Ranger Station Gulch (located just north of Saddle Mountain). What apparently happened is prior to a reversal of flow in what is now northeast-oriented Elevenmile Canyon a large stream of southeast-oriented water flowed from the South Platte River alignment across what are now the two divide crossings and then along the Brooker Gulch and Cobb Creek alignments to south-oriented Fourmile Creek and was captured by northeast-oriented Fish Creek valley headward erosion and next by the reversal of flow on today's northeast-oriented South Platte River valley along the Elevenmile Canyon alignment. These captures are difficult to explain unless large volumes of water flowing in diverging and converging channels were involved.

DC-9 at an elevation of 2685 meters is lower than any of the previous divide crossings and is located near the south end of the north-oriented Fish Creek segment and links that north-oriented Fish Creek valley segment with southsoutheast oriented Slater Creek which flows to south-oriented Fourmile Creek. Before the South Platte River flow reversal in the now northeast-oriented Elevenmile Canyon large volumes of water apparently flowed in a south direction into what is now the Fourmile Creek drainage basin and then to the Arkansas River (downstream from Royal Gorge). While the South Platte River valley flow reversal was still underway Fish Creek valley headward erosion cut what is now the Fish Creek water gap across the south end of Blue Mountain, which resulted in the beheading and reversal of south-oriented flow to Slater Creek and which created a north-oriented Fish Creek segment. Headward erosion of the northeast-oriented Fish Creek headwaters segment from the south end of that reversed flow segment next captured south-oriented water that had been flowing across DC-9.

DC-10 (seen in Figure 4) is located south of the Florissant Fossil Beds National Monument, has an elevation of 2615 meters (lower than DC-9), and links north-oriented Grape Creek (draining to northwest-oriented Twin Creek and the north-oriented South Platte River) with south-oriented Hay Creek (draining to south-oriented Fourmile Creek and the Arkansas River). Other, somewhat 


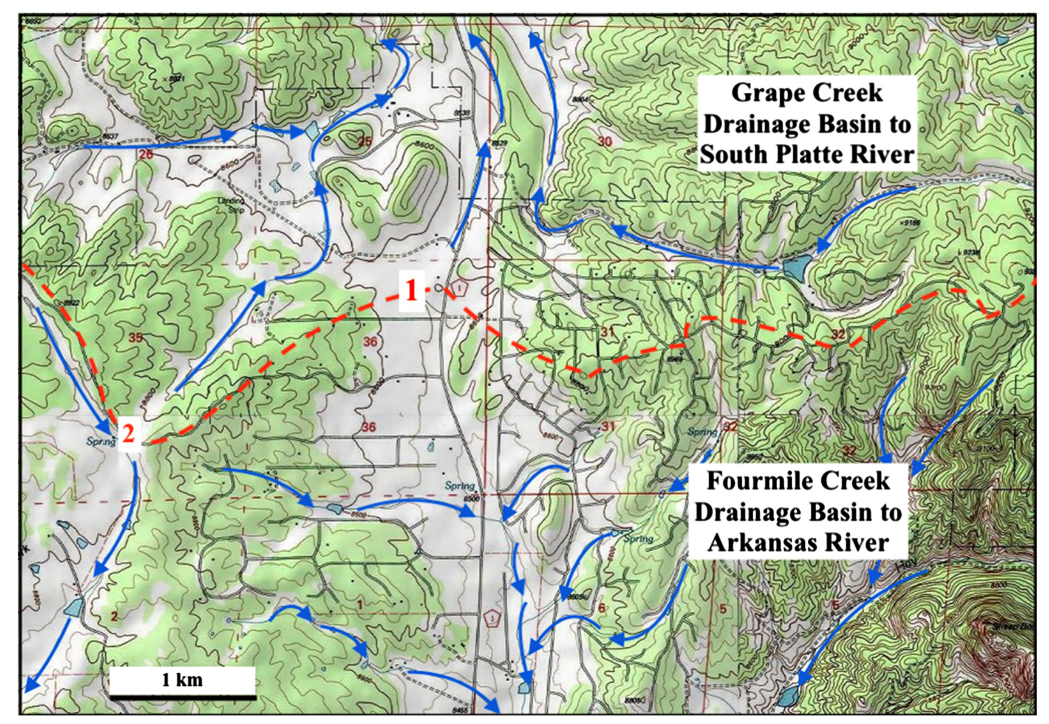

Figure 4. Modified topographic map from the USGS National Map website showing the Grape Creek-Fourmile Creek drainage divide location (red dashed line) south of the Florissant Fossil Beds National Monument. Contour interval is 40 feet (12 meters).

higher elevation divide crossings in the Florissant Fossil Beds National Monument area connect abandoned valleys and suggest a large complex of diverging and converging channels eroded the region. Floodwaters arriving in the area may have flowed in a southeast and then south-southeast direction along what is now the Tarryall Creek and Tappan Gulch alignments before crossing the present-day north-oriented South Platte River alignment and then proceeding in a southeast and south direction to reach what is now the Fourmile Creek drainage basin. A flow reversal in the now north-oriented South Platte River valley caused southeast-oriented Tarryall Creek to turn in a northeast direction to along what had been a southwest-oriented diverging channel and to behead southeast-oriented flood flow moving along the south-southeast oriented Tappan Gulch alignment (see Figure 5). These captures would only have been possible if large volumes of southeast- and south-oriented floodwater had been flowing across the region on a surface at least as high as the DC-10 elevation is today.

DC-11 with an elevation of 2865 meters is notched into the west end of Tracy Hill and links south-oriented Fourmile Creek with north- and northeast-oriented Rule Creek (flowing to north and north-northwest oriented Trout-Horse Creek (after joining north-oriented West Creek, Trout Creek becomes Horse Creek, see Figure 6), which joins the north-oriented South Platte River). Before turning south (south of Tracy Hill) Fourmile Creek headwaters flow in southwest, northwest, and southwest directions suggesting a complex capture history. The DC-11 elevation is similar to elevations of divide crossing located to the west of the Elevenmile Canyon area and may be an indication of the regional surface elevation prior to deep erosion as south-oriented floodwaters eroded the Florissant Fossil Bed National Monument region more deeply. 


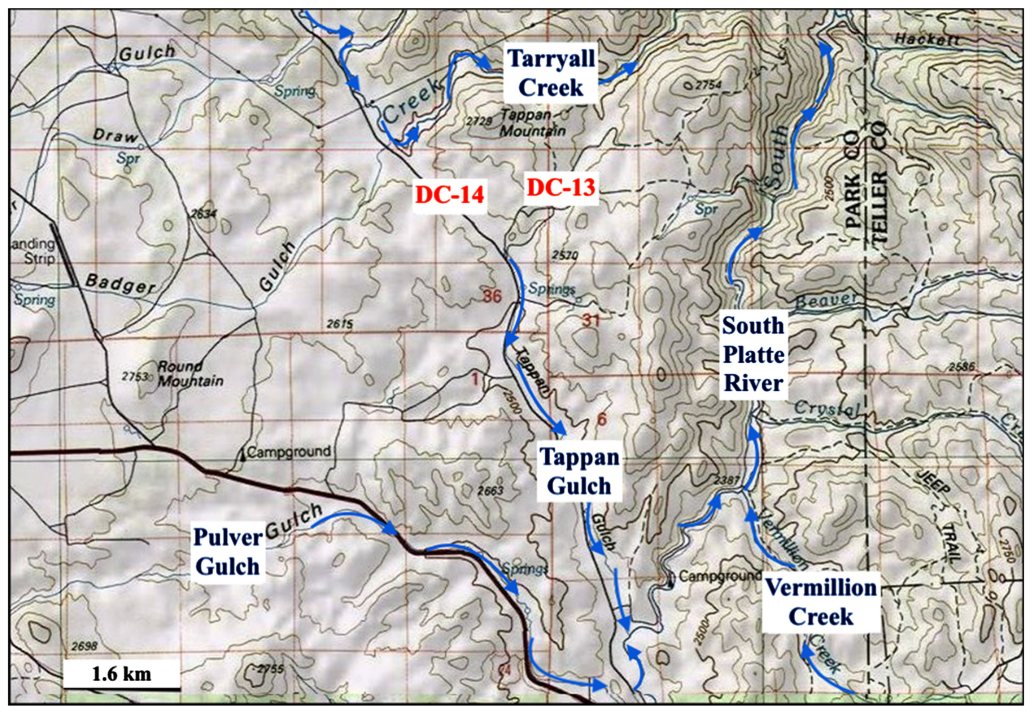

Figure 5. Modified topographic map from the USGS National Map website showing abandoned valleys (DC-13 and DC-14) providing evidence for former south-oriented flow on what in now the north-oriented South Platte River. Contour interval 50 meters.

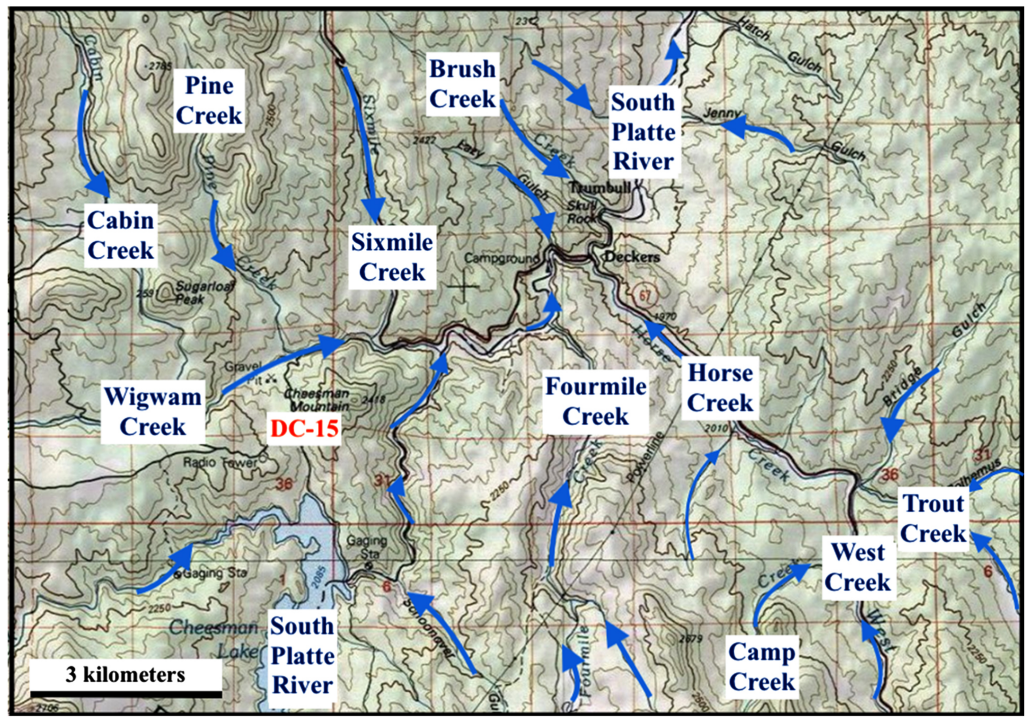

Figure 6. Modified topographic map from USGS National Map website showing northand south-oriented tributaries flowing to north-northeast oriented South Platte River. DC-15 identifies a divide crossing discussed in the text. Contour interval is 50 meters.

DC-12 has an elevation of 2590 meters, is located at Woodland Park, and links north and north-northwest oriented Trout-Horse Creek with southeast- and south-oriented Fountain Creek (flowing to Colorado Springs and the Arkansas River at Pueblo). Numerous slightly-higher elevation divide crossings in the Woodland Park area connect diverging and converging abandoned valleys and suggest erosion by massive south-oriented floods that were beheaded and reversed to create the north-oriented Trout-Horse Creek drainage route. Today north-oriented Trout-Horse Creek turns in a northwest direction before joining the north-northeast oriented South Platte River at Deckers, however prior to the 
flow reversal it is probable that south-oriented floodwaters from the north diverged at Deckers with some water continuing in a south direction along today's north-oriented South Platte River alignment and some water flowing in a southeast and the south direction on the Horse-Trout-Fountain Creek alignment along which water diverged multiple times to flow in south directions along what are now the north-oriented West Creek alignment and the alignments of other north-oriented Trout-Horse Creek tributaries. The depth of DC-12 when compared with depths of the other discussed divide crossings suggests large and prolonged volumes of south-oriented water once flowed through the Woodland Park area to Fountain Creek and then to the Arkansas River.

A reversal of flow in the now north-northeast oriented South Platte River valley is further supported by DC-13 and DC-14 (seen in Figure 5) and which are located along the Tarryall Creek-Tappan Gulch drainage divide. Tarryall Creek originates near deep passes along the east-west continental divide and flows in a southeast direction across northern South Park to enter Figure 5 map area where it turns to flow in a northeast direction to join the north-oriented South Platte River (north of the figure). DC-13 is located in an abandoned north-northeast to south-southwest oriented valley linking the northeast-oriented Tarryall Creek segment with the south-southeast oriented Tappan Gulch valley (draining to the north-oriented South Platte River as a barbed tributary). DC-14 is located in an abandoned valley linking the southeast-oriented Tarryall Creek headwaters valley with the south-southeast oriented Tappan Gulch valley. Prior to the flow reversal that created the north-oriented South Platte River one stream of southoriented water flowed along what is now the north-oriented South Platte River alignment while a diverging stream of south-oriented water flowed in a southwest direction along what is now the northeast-oriented Tarryall Creek alignment to DC-13 and then joined southeast-oriented Tarryall Creek, which at that time flowed in a southeast direction across DC-14 and along the Tappan Gulch alignment to join south-oriented water on what is now the north-oriented South Platte River alignment. Just south of Figure 5 some south-oriented water turned in a southeast and then south direction to enter Figure 4 map area while another diverging stream of water probably flowed in a southwest direction along what is now the northeast-oriented South Platte River Elevenmile Canyon alignment. Note also in Figure 5 north-oriented Vermillion Creek which probably flows on the alignment of what was once a diverging south-oriented flood flow channel and Pulver Gulch (which to the west of the figure has southeast-oriented headwaters and which in the figure joins the north-oriented South Platte River as a barbed tributary).

The drainage pattern seen in Figure 6 is difficult to explain from an accepted paradigm perspective, but much easier to explain when viewed from the new paradigm perspective. For example, note how there are as many south-oriented drainage routes as there are north-oriented drainage routes. DC-15 in Figure 6 identifies a north-to-south oriented divide crossing which links south-oriented Pine Creek with the north-northeast-oriented South Platte River. Headward ero- 
sion of the east-northeast Wigwam Creek valley across what must have been massive south-oriented flood flow captured not only south-oriented Pine Creek, but also south-oriented Sixmile and Cabin Creeks and then what are today extensive southeast-oriented Wigwam Creek headwaters (to the west of the figure). That capture probably occurred when headward erosion of the east- and northeast-oriented South Platte River valley (to the north of Denver) beheaded and reversed south-oriented flood flow moving along what is now the north-oriented South Platte River valley (to the south of Denver). That beheading and reversal of south-oriented floodwaters also caused a much deeper north-oriented valley to erode headward (in a south direction) along what is now the north-northeast oriented South Platte River alignment which in turn beheaded and reversed in sequence all south-oriented diverging and converging flood flow channels it crossed so as to create what are now north-oriented South Platte River tributaries. In other words, north-oriented South Platte River tributaries such as Trout, West, Camp, Horse, and Fourmile Creeks seen in Figure 6 originated as components of a large south-oriented diverging and converging flood formed channel complex.

\section{Discussion}

With the exception of DC-1, DC-13, DC-14 and DC-15 all of the described divide crossings suggest large floods of south-oriented water flowed from the northoriented South Platte River drainage basin into the southeast- and east-oriented Arkansas River drainage basin while DC-13, DC-14 and DC-15 suggest the now north-oriented South Platte River valley originated as a south-oriented flood flow channel. Further, many divide crossings are eroded across areas directly or indirectly affected by Thirtynine Mile volcanic activity and are younger than the volcanic affected materials. Previous (accepted paradigm) investigators such as Epis and Chapin (1975) suggested the Thirtynine Mile volcanic activity occurred on top of a southward sloping late Eocene peneplain surface and identified paleovalleys cut in that surface. If those paleovalleys predate Thirtynine Mile volcanic activity and the divide crossings described here postdate the volcanic activity the Thirtynine Mile volcanic activity may have occurred as massive south-oriented floods flowed across the region and may be indirectly related to the flood source.

Likewise, the flow reversal in the now north-oriented South Platte River valley enabled a deeper north-oriented valley to erode headward (in a south direction) along what had been south-oriented flood flow channels. To explain the South Platte River flow reversal tectonic uplift must have raised the South Platte River headwaters region relative to regions further to the north and the tectonic activity must have occurred as the southeast- and south-oriented floods flowed across the region. Such a scenario is inconsistent with accepted paradigm interpretations, but is what the new paradigm predicts. The South Platte River headwaters area is located along a segment of the new paradigm's deep "hole" rim which was being raised by continental ice sheet caused crustal uplift as massive 
south-oriented meltwater floods first flowed across it and were subsequently diverted by the rim uplift to flow along the rim and eventually to flow toward the deep "hole." As deep "hole" rim uplift progressed the south-oriented Mississippi River became the only deep "hole" southern outlet and at first valleys such as the Arkansas River valley eroded headward in a westward direction from that outlet to divert south-oriented floodwaters toward that outlet. But as deep "hole" rim uplift and headward erosion of the Mississippi River valley outlet progressed the Missouri River valley eroded headward to not only divert south-oriented floodwaters toward the Mississippi River outlet but also to capture south-oriented floodwaters from further to west which the deep "hole" rim uplift was diverting in north directions and into the developing deep "hole".

Many southeast-oriented South Platte River headwaters and tributaries now begin in formerly glaciated mountain regions located along the east-west continental divide which means the massive south-oriented meltwater floods must have flowed across what is now the southwest-oriented Colorado River headwaters drainage basin (as described in a previously cited new paradigm demonstration paper [16]). Headward erosion of the deep southwest-oriented Colorado River valley into what must have been a rising deep "hole" rim region progressively captured (from west to east) south- and southeast-oriented floodwaters moving toward the South Platte River headwaters area. This new paradigm interpretation implies that as deep "hole" rim uplift began large south-oriented meltwater floods also entered the Colorado River drainage basin. New paradigm demonstration papers not previously cited show south-oriented meltwater floods also flowed across what is now the Wyoming Great Divide Basin into the Colorado River drainage basin [23] [24] and within the Colorado River drainage basin across what is now the Yampa River-Colorado River drainage divide to reach the Colorado River valley [25]. While not the subject of this paper these new paradigm demonstration papers document immense volumes of meltwater which must have entered the Colorado River drainage basin and which were probably responsible for many Colorado River drainage basin erosional features. More pertinent to this paper's geographic area the evidence presented here documents how headward erosion of a deeper north-oriented South Platte River valley along what had been south-oriented flood flow channels (in the region south of Denver) captured south- and southeast-oriented flood flow, which had been moving to the Arkansas River valley and which Colorado River valley headward erosion subsequently captured.

The new paradigm interprets the mountain glaciation to have occurred after deep "hole" rim uplift had diverted meltwater floods to flow into deep "hole" space being opened up as the thick ice sheet melted. At first diverted meltwater floods flowed into large ice-walled canyons near the ice sheet's southern margin through which the floodwaters then flowed to southern exits via routes leading to the developing Mississippi and Missouri River valleys, although as the ice sheet decayed and the ice-walled canyon network expanded eventually meltwater floods flowed in north directions between decaying ice sheet remnants to the 
North Atlantic and Arctic Oceans. This diversion of meltwater floods and other north-oriented drainage from the Gulf of Mexico to northern oceans changed the climate which led to the freezing of the north-oriented drainage around decaying thick ice sheet remnants and which created a much thinner ice sheet. By that time deep "hole" rim uplift had raised the South Platte River headwaters area to about its present-day elevation which combined with the much colder climate led to mountain glaciation which modified the mountain landscape and which produced meltwater which transported glacial debris downstream into the then newly formed South Platte River drainage system, although the mountain glaciation did not significantly alter the previously developed South Platte-Arkansas River drainage divide.

\section{Conclusions}

Previous researchers have ignored detailed topographic map evidence for most drainage systems and erosional landform features including divide crossings, abandoned valleys, barbed tributaries, and diverging and converging channel evidence. These features are easily studied on detailed topographic maps (now available at the USGS National Map website) and can be easily used to reconstruct previous drainage systems. Understanding drainage system evolution is critical if a region's Cenozoic history is to be properly understood. Ignoring detailed topographic map drainage system and erosional landform evidence has led previous researchers to develop an accepted Cenozoic geologic and glacial history paradigm unable to explain much of the detailed topographic map drainage history and erosional landform evidence. The ignored detailed topographic map drainage system and erosional landform evidence has now been used to develop a new and fundamentally different Cenozoic geologic and glacial history paradigm which as described and illustrated here explains many previously unexplained or poorly explained South Platte River headwaters drainage basin features (south of Denver).

The new paradigm as demonstrated here explains divide crossings located along the present-day South Platte River-Arkansas River drainage divide. Multiple clusters of closely spaced divide crossings indicate large and prolonged south-oriented floods (some of which had crossed what is now the deep southwest-oriented Colorado River headwaters valley) flowed across the South Platte River headwaters drainage basin (to the south of Denver) at a time when Thirtynine Mile volcanic activity was probably taking place. Abandoned valleys and barbed tributaries also indicate the present-day north-northeast oriented South Platte River valley almost certainly originated as one or more south-oriented flood flow channels. These interpretations are inconsistent with accepted paradigm expectations, but are consistent with new paradigm predictions in which the South Platte River headwaters drainage basin is located on a deep "hole" rim raised by thick continental ice sheet caused crustal uplift as large south-oriented meltwater floods first flowed across the rising rim and were later forced by the 
deep "hole" rim uplift to flow in southeast and east directions toward the evolving south-oriented Mississippi River valley and finally were forced to flow in north and northeast directions toward deep "hole" space located between the rising deep "hole" rim and the melting ice sheet.

\section{Acknowledgements}

Preliminary work leading to the new paradigm was done while employed as a Minot State University faculty member where other faculty members, students, and library staff members assisted in providing access to hard copy topographic maps. During the mid 1960s Arthur Strahler, then at Columbia University, and Brainerd Mears, Jr., then at the University of Wyoming introduced numerous unsolved drainage history problems.

\section{Conflicts of Interest}

The author declares no conflicts of interest regarding the publication of this paper.

\section{References}

[1] Scarbrough Jr., L.A. (2001) Geology and Mineral Resources of Park County, Colorado. Colorado Geological Survey Resource Series No. 40, Colorado Geological Survey, Denver, $89 \mathrm{p}$.

[2] Barkmann, P.E., Sebol, L., Fitzgerald, F.S. and Curtiss, W. (2015) Geology and Groundwater Resources of Park County, Colorado. Open-File Report 15-11, Geological Survey and Colorado School of Mines, $69 \mathrm{p}$.

[3] Kuhn, T.S. (1970) The Structure of Scientific Revolutions. 2nd Edition, Enlarged, The University of Chicago Press, Chicago, 210 p.

[4] Clausen, E. (2020) Analyzing Anomalous Topographic Map Drainage System and Landform Evidence as a Glacial History Paradigm Problem: A Literature Review. Open Journal of Geology, 10, 1072-1090. https://doi.org/10.4236/ojg.2020.1011052

[5] Stark, J.T., Johnson, J.H., Behre, C.H., Jr., Powers, W.E., Howland, A.L., Gould, D.B., et al. (1949) Geology and Origin of South Park Colorado. Memoir No. 33, Geological Society of America, 188 p. https://doi.org/10.1130/MEM33-p1

[6] Fenneman, N.M. (1931) Physiography of the Western United States. McGraw-Hill Book Company, Inc., New York, 534 p.

[7] Thornbury, W.D. (1965) Regional Geomorphology of the United States. John Wiley and Sons, Inc., New York, 609 p.

[8] Atwood, W.W. (1940) The Physiographic Provinces of North America. Ginn and Company, Boston, 536 p.

[9] Pelletier, J.D. (2009) The Impact of Snowmelt on the Late Cenozoic Landscape of the Southern Rocky Mountains, USA. GSA Today, 19, 4-10.

https://doi.org/10.1130/GSATG44A.1

[10] Epis, R.C. and Chapin, C.E. (1975) Geomorphic and Tectonic Implications of the Post-Laramide, Late Eocene Erosion Surface in the Southern Rocky Mountains. In Curtis, B.F., Ed., Cenozoic History of the Southern Rocky Mountains, Memoir No. 44, Geological Society of America, 45-75. https://doi.org/10.1130/MEM144-p45

[11] McGookey, D.P. (2002) Geologic Wonders of South Park, Colorado with Road 
Logs. Donald P. McGookey, Midland Texas, 174 p.

[12] Wobus, R.A. and Epis, R.C. (1978) Geologic Map of the Florissant 15-Minute Quadrangle, Park and Teller Counties, Colorado. United States Geological Survey Miscellaneous Investigations Series Map I-1044. Scale 1:62,500. United States Geological Survey, Reston. https://doi.org/10.3133/ofr79426

[13] Epis, R.C., Wobus, R.A. and Scott, G.R. (1979) Preliminary Geologic Map of the Guffey Quadrangle, Park County, Colorado. United States Geological Survey Miscellaneous Investigations Series Map I-1180, Scale 1:62,500. United States Geological Survey, Reston.

[14] Meyer, H.W., Veatch, S.W. and Cook, A. (2004) Field Guide to the Paleontology and Volcanic Setting of the Florissant Fossil Beds, Colorado. In: Nelson, E.P. and Erslev, E.A., Eds., Field Trips in the Southern Rocky Mountains, USA, Field Guide No. 5, Geological Society of America, Boulder, 151-166.

https://doi.org/10.1130/0-8137-0005-1.151

[15] Benson, M.E. (2011) Freshwater Diatom Paleontology and Paleolimnology of the Late Eocene Florissant Formation, Teller County, Colorado. PhD thesis, University of Colorado, Boulder, $427 \mathrm{p}$.

[16] Clausen, E. (2020) Topographic Map Analysis of Mountain Passes Crossing the Continental Divide Between Colorado River Headwaters and North and South Platte River Headwaters to Test a New Geomorphology Paradigm, Colorado, USA. Journal of Geography and Geology, 12, 50-64. https://doi.org/10.5539/jgg.v12n1p50

[17] Clausen, E. (2021) Topographic Map Analysis of the North Platte River-South Platte River Drainage Divide Area, Western Larimer County, Colorado, USA. Earth Science Research, 10, 49-60. https://doi.org/10.5539/esr.v10n1p49

[18] Clausen, E. (2018) Topographic Map Analysis of Laramie Range Bedrock-Walled Canyon Complex and the Goshen Hole Escarpment-Surrounded Basin, Albany and Platte Counties, Southeast Wyoming, USA. Open Journal of Geology, 8, 33-55. https://doi.org/10.4236/ojg.2018.81003

[19] Clausen, E. (2019) Use of Stream and Dismembered Stream Valleys Now Crossing Wyoming's Northern Laramie Mountains to Test a Recently Proposed Regional Geomorphology Paradigm. Open Journal of Geology, 9, 731-751. https://doi.org/10.4236/ojg.2019.911087

[20] Clausen, E. (2020) North Platte River-South Platte River Confluence Area Drainage System History as Determined by Topographic Map Interpretation: Western $\mathrm{Ne}$ braska, USA. Journal of Geography and Geology, 12, 28-39. https://doi.org/10.5539/jgg.v12n2p28

[21] Clausen, E. (2020) Use of Detailed Topographic Map Evidence of the Southeast Wyoming Gangplank Area to Compare Two Fundamentally Different Geomorphology Paradigms, USA. Open Journal of Geology, 10, 261-279.

https://doi.org/10.4236/ojg.2020.104014

[22] Tweto, O., Moench, R.H. and Reed, J.C. (1978) Geologic Map of the Leadville 1 degree $\mathrm{x} 2$ degrees quadrangle, northwest Colorado. Miscellaneous Investigations Map I-999, United States Geological Survey, Reston.

[23] Clausen, E. (2019) Use of Topographic Map Evidence to Test a Recently Proposed Regional Geomorphology Paradigm: Wind River-Sweetwater River Drainage Divide Area. Central Wyoming, USA. Open Journal of Geology, 9, 404-423. https://doi.org/10.4236/ojg.2019.98027

[24] Clausen, E. (2020) Use of Topographic Map Evidence from Drainage Divides Surrounding Wyoming's Great Divide Basin to Compare Two Fundamentally Different 
Regional Geomorphology Paradigms. Earth Science Research, 9, 45-57. https://doi.org/10.5539/esr.v9n1p45

[25] Clausen, E. (2021) Yampa River-Colorado River Drainage Divide Origin Determined from Topographic Map Evidence, Southern Routt County, Colorado, USA. Open Journal of Geology, 11, 319-339. https://doi.org/10.4236/ojg.2021.118017 